\title{
Investigation of the Factors That Effect the University Students' Desperation Levels (Kafkas University Example)
}

\author{
Kübra ÖZDEMIR ${ }^{1}$, Ali Osman ENGIN² \& Ahmet Gökhan YAZICI ${ }^{1}$ \\ ${ }^{1}$ Physical Education and Sports, Kazım Karabekir Faculty of Education, Atatürk University, Erzurum, Turkey \\ ${ }^{2}$ Department of Education and Tranining Programs, Kazım Karabekir Faculty of Education, Atatürk University, \\ Turkey \\ Correspondence: Kübra ÖZDEMIR, Physical Education and Sports, Kazım Karabekir Faculty of Education, \\ Atatürk University, Erzurum, Turkey. E-mail: kubra.ozdemir@atauni.edu.tr
}

Received: August 22, 2020 Accepted: September 24, $2020 \quad$ Online Published: September 30, 2020

doi:10.5539/jel.v9n5p270 URL: https://doi.org/10.5539/jel.v9n5p270

\begin{abstract}
The desperation is a kind of negative foresight on the contrary of positive foresight for the future. That is to say, to some extend, and it is an emotional situation having negative expectations for the future. The aim of the study, determination the factors that are affecting the university students' desperation levels. This study was conducted to examine the students of Kafkas university despite levels for the future. The sampling groups of this study were the students of Kafkas University Education Faculty educated at Physical Education and Sports Department (25 students), Basic Mathematics Teaching Department (25 students), Science Teaching Department (25 students), and Social Studies Teacher's Department (25 students) 4th class totally 100 participant students in 2016-2017 academic year. The sampling group was selected using simple random - the data handed with the help of the data collecting scale evaluated by using the SPSS Package Program. The preferences are "Yes (Correct) and No (Wrong)". As a result of this study, there wasn't a meaningful difference in the participant students' desperation levels according to the variables. Students' desperation level means were lower than $\mathrm{p}<0.05$.
\end{abstract}

Keywords: desperation, depression, future

\section{Introduction}

Mental health concerns the individual's ability to cope with the normal stress of life and contribute to society (Veness, 2016). Many mental health problems (e.g., anxiety, depression, schizophrenia, and bipolar disorder) may result in an individual's decreased capacity to coping with the normal request of life (Usher, 2020).

Depression is an important issue worldwide and it is characterized by decreased motivation, seriously endangering people's mental and physical health (Alexopoulos, 2019; de Aguiar Neto \& Rosa, 2019; Górska et al., 2019; Tao et al., 2020). Globally, more than 264 million people of all ages suffer from depression (James et al., 2018; Duko et al., 2020). It has been a leading cause of disability worldwide and contributes greatly to the overall burden of disease (Jantaratnotai et al., 2017; Belayihun \& Mavhandumudzuis, 2018; Breslow et al., 2019; Kingston et al., 2020). It affects $2 \%$ of pre-pubertal children and between 5 and $8 \%$ of adolescents worldwide (Stephens et al., 2020). Childhood depression can result in many health, social and academic issues (Grover \& Avasthi, 2019; Sekhar et al., 2019).

As it is known that the university years are the time periods fot the students to live many physical and social problems together. Beyond having the possibility of university education leaving family and known environment and getting used to the new environment, having new friends and environment, and facing a lot of problems such as anxiety about the professional life. These social, cultural and economic changes may affect young people negatively (Cam \& Erkorkmaz, 2008).

The living social and psychological problems, being a university student, education and unemployment problems, affect the adolescents' spiritual growth negatively. One of the important psychological problems in this time period is desperation. Generally, in the context of long-term conflict, spreading despair is easier than instilling hope. Hope is a feeling activated when it visualizes a desired and meaningful aim in the future, followed by a positive opportunity in mental state (Cohen - Chen et al., 2020). It expressing the sense of having positive expectations for the future affects mental health positively by giving people the feeling that they can cope with 
the negative experiences they may encounter in the future. In intergroup conflicts, hope has been found to be related to concession-making (Rosler et al., 2017), positive intergroup behavior (Lala et al., 2014), forgiveness (Moeschberger et al., 2005), and willingness to provide humanitarian aid (Halperin \& Gross, 2011). Recently, experimentally induced hope has been displayed to rise attitude opportunity (Cohen-Chen et al., 2014; Cohen-Chen et al., 2017). As is the case of hope, despair is induced when attempting to think about and imagine the future. However, unlike hope, despair is rooted within feelings of uncertainty (Sallfors et al., 2002), futility, and an inability to imagine a positive future.

Hope and despair express the possibility of fulfilling the expectations of the individual for the future. Despair is defined as individuals believing that they will never overcome their failures, they can never solve their problems, they have false implications for their lives without a real reason, and expect negative results from them, although they do not strive to achieve their goals. Also, despair is defined as negative expectations less than zero in achieving a goal (Kula \& Saraç, 2017).

The young have been facing many problems during the university years. Especially the undergraduate students who leave their families educated in different cities had their individual responsibilities mostly. There is much immortality in this process; the danger of unemployment, poverty, striving to gain social status affect the young brains the most. In addition to them, when we add uncertainty in the common position of the country, the amount of young is getting less and less. Some of the new arrangements about the teachers have roles to increase the desperation levels of the candidate teachers. The uncertainty of the national support and state security created frustration for the education faculty graduates. In addition to this, the oral exam/interview practices break the eagerness to work and support the uncertain position. As it is thought in such a context, the candidate teachers graduated from education faculties begin to have more and more desperation level. If so, in what healthy extend of the teachers and teacher candidates' psychological and professional qualifications are having desperation for the future? This is a controversial issue.

The purpose of this study is to investigate the hopelessness level of the senior students at Kafkas University in terms of some various variables.

\subsection{Problem Sentence/Question}

*What is the desperation level of the students educated at education faculty?

\subsection{Sub Problem Sentences/Questions}

The students educated at education faculty:

1) Is there a meaningful difference among the participant students' desperation levels according to the sex variable?

2) Is there a meaningful difference among the participant students' desperation levels according to the main branch variable?

3) Is there a meaningful difference among the participant students' desperation levels according to the perceived income variable?

\subsection{The Importance of This Study}

Growing the hope of promising individuals up or educating the hope of promising individuals in a society is in the hand of their parents first and secondly, it is the duty of their teachers. For that reason, the teachers' qualities, psychological health, self-perception, perspectives on life affect their students in many dimensions. The teacher candidates had these gains during the university years. The answer to each question about how and how much the teacher candidates carry these features is pretty important. In this study, particularly it was tried to study the teacher candidates' desperation levels. Because maybe while the hope is a beginning point of everything, the desperation is a factor to stop and finish many features/possibilities. A negative point of view and idea of a teacher candidate for the future is the reason that causes to lose his or her positive psychology, self-esteem, expectation from life and such as living energy to be an indispensable factor. It is a suspicious truth about how to gain the necessary awareness. In this study it was aimed to develop the awareness of this situation and reveal it objectively.

\subsection{Suppositions}

It was assumed that the teacher candidates chose the preferences of the data collecting scale correctly, consciously, and sincerely. 


\subsection{Limitations}

This study was limited by the students educated in Kafkas University Education Faculty at Physical Education and Sports Department, Basic Mathematics Teaching Department, Science Teaching Department and Social Studies Teacher Department's 4th class participant students in the 2016-2017 academic year.

\section{Method}

In this study, a descriptive scanning model was used. This model is related to how to express the existed variables objectively. In this study, the participant students educated at different departments of Kafkas University Education Faculty were chosen/defined, such as sampling groups and their desperation levels were studied on.

It was accepted that the universe of this study was the education faculty teacher candidate undergraduate students in Turkey. The sampling groups of this study were the students of Kafkas University Education Faculty educated at Physical Education and Sports Teacher Department (25 students), Basic Mathematics Teaching Department (25 students), Science Teaching Department (25 students) and Social Studies Teacher's Department (25 students) 4th class totally 100 participant students in 2016-2017 academic year. The sampling group was selected randomly.

\subsection{Model of Research}

In the current research, a general survey model, one of the descriptive research methods, was used. The general survey model was described in Karasar (2005) as a research method that aims to define an existing situation according to a previous study (Karayol \& Doğar, 2020).

\subsection{Data Collection Tools}

In this study "Beck Desperation Scale" developed by Beck, Lester and Trexler (1974) was used to collect the data and revised according to Teshome Hambisa et al. (2020). It has been recognized as a powerful tool to determine depression mood (De Berardis et al., 2017). This scale contains 20 items and the items have two preferences. They are "Yes" and "No". This scale is a kind of self-assessment scale and is scored in the range of $0-1$. The score range of the scale is between $0-2$. The "Yes" preference for the 11 items of the scale takes 1 point and for the 9 items, "No" preference takes 1 point too. If the points are high, it is accepted that the desperation level is high.

\subsection{Data Analysis}

In this study, two different statistical analysis methods were used to evaluate the data with the help of the SPSS 22.00 Package program. These methods were; Mann Whitney U Test and Kruskal Wallis H Test. As a result of these tests to understand if the data showed normal variation or not Kolmogrow-Smirnow and Shapiro-Wilk's results were found meaningful at the importance level of $p<0.05$. Because of this result, it was understood that the data were not suitable for normal parametric variation. So nonparametric analysis was used to evaluate the data.

Table 1. Skewness ve Kurtosis analysis

\begin{tabular}{lllllll}
\hline & \multicolumn{5}{l}{ Kolmogorov-Smirnov $^{\mathrm{a}}$} & \multicolumn{3}{l}{ Shapiro-Wilk } \\
\cline { 2 - 7 } & Statistic & S.d & $\mathrm{p}$ & Statistic & S.d & $\mathrm{p}$ \\
\hline TOTAL & .200 & 100 & .000 & .887 & 100 & .000 \\
\hline
\end{tabular}

Note. a. Lilliefors Significance Correction.

\section{Result and Discussion}

In this study, it was tried to find out the university students' desperation levels according to some variables. They were; sex, undergraduate program, income level, main branch department. As a result of this study, there wasn't a meaningful difference in the participant students' desperation levels according to the variables. Students' desperation level means were lower than $\mathrm{p}<0.05$. 
Table 2. The data/findings related to students' defining/demographic features

\begin{tabular}{lcc}
\hline & $\mathrm{n}$ & $\%$ \\
\hline Sex & 61 & \\
Female & 39 & 31.0 \\
Male & & \\
\hline Undergraduate Program & 50 & 50.0 \\
Numerical & 50 & 50.0 \\
Verbal & & \\
\hline Income Level & 39 & 39.0 \\
$0-1000$ TL & 47 & 47.0 \\
1000-2500 TL & 14 & 14.0 \\
\hline Main Branch Department & & \\
Social Studies Teacher & 25 & 25.0 \\
Physical Education and Sports Teacher & 25 & 25.0 \\
Science Teacher & 25 & 25.0 \\
Math Teacher & 25 & 25.0 \\
\hline
\end{tabular}

When Table 2 examined the participant students, $61 \%$ were female and $39 \%$ were male and $50 \%$ of them had education in the numerical program and $50 \%$ of them had education in the verbal program. $39 \%$ of the participant students' incomes were about 0-1000 Turkish Liras, 14\% of the participants had 1000-2500 Turkish Liras as income and 14\% of them had 2500 and more than 2500 Turkish Liras as income. On the other hand, 25\% of participants were from Social Studies Teacher, 25\% were from Physical Education and Sports Teacher, 25\% were from Science Teacher and 25\% were from Math Teacher departments.

Table 3. Participant students' standart deviation and mean scores related to desperation scale

\begin{tabular}{llllll}
\hline & $\mathrm{N}$ & Minimum & Maximum & Arithmetic Mean & S.s. (S.D.) \\
\hline Total Score of Desperation Scale & 100 & .00 & 20.00 & 6.67 & 5.45 \\
\hline
\end{tabular}

When Table 3 was examined, it was understood that the students' desperation score means were about $6.67 \pm$ 5.45 .

Table 4. Differences about the students' desperation scores according to their defining/demographic features

\begin{tabular}{|c|c|c|c|c|c|}
\hline & $\mathrm{N}$ & Row mean & Row total & Test & $\mathrm{p}$ \\
\hline \multicolumn{6}{|l|}{ Sex } \\
\hline Female & 61 & 50.22 & 3063.50 & $\mathrm{U}=1172.500$ & .904 \\
\hline Male & 39 & 50.94 & 1986.50 & & \\
\hline \multicolumn{6}{|l|}{ Undergraduate Program } \\
\hline Numerical & 50 & 50.20 & 2510.00 & $\mathrm{U}=1235.000$ & .917 \\
\hline Verbal & 50 & 50.80 & 2540.00 & & \\
\hline \multicolumn{6}{|l|}{ Income Level } \\
\hline $0-1000 \mathrm{TL}$ & 39 & 52.26 & & $\mathrm{KW}=.256$ & .880 \\
\hline $1000-2500 \mathrm{TL}$ & 47 & 49.10 & & & \\
\hline 2500 and above TL & 14 & 50.32 & & & \\
\hline \multicolumn{6}{|l|}{ Main Branch Department } \\
\hline Social Studies Teacher & 25 & 48.66 & & $\mathrm{KW}=463$ & .927 \\
\hline Physical Education and Sports Teacher & 25 & 52.94 & & & \\
\hline Science Teacher & 25 & 48.48 & & & \\
\hline Math Teacher & 25 & 51.92 & & & \\
\hline
\end{tabular}

When Table 4 was examined, it was understood that there wasn't a meaningful difference in their desperation scores according to their demographic features such as sex, undergraduate program, income level and main branch unit. Because all the differences were higher than $p<0.05$ meaning level. These findings showed that there wasn't a meaningful difference. 
Özmen and Dilek et al. (2008) studied on the subject of "The factors affecting the high school students' dissertation levels." In this study they found out that generally, the high school students were hopeful about the future but on the other hand there were some desperate students too. As a result of this study, the children grown up by some families having lower rate income level were more desperate ones. These findings do not support our study.

Ceyhan (2004), in the study named "The examination of the teacher candidates desertion levels continuing the program of graduate education without thesis in the teaching area of secondary education", defined that beyond the teacher candidates' desertion levels were low, some teacher candidates were living more leveled desertion and the male teacher candidates had more leveled desertion than female teacher candidates. According to another data of this study was that; the teacher candidates who were having the hope of being appointed had higher desertion levels than the teacher candidates, not having the hope of not being appointed. These findings are not in line with our study.

Ayda (2011), in the study called "The definition of the music department undergraduate students dissertation levels: The example of Ankara State Conservatory of Hacettepe University", it was found out that according to the data; the candidate teachers had higher desertion levels at desertion sub-dimension related to the emotion and expectation, motivation lose and hope for the future. On the other hand, the candidate teachers had lower levels of desertion distributed in the sub-dimensions of feeling and expectations. As a result, according to the high schools that the candidate teachers graduated from, there was a meaningful difference related to the dissertation levels. These findings are not in line with our study.

Şahin (2009) studied a similar subject. In the study called "The desperation levels of students educated at education faculty", it was tried to find out the student's desertion levels were low, but there were some students who were living high level of desertion feeling according to the variables of sex, main department branches, living areas and income levels. So is there were meaningful differences in the dissertation levels. But according to the class level, parents' education levels, there weren't a meaningful difference. These findings do not support our study.

Doğan (2012) defined in the study named "Investigation of art candidate teachers' desertion levels" that they had a low level of desertion. On the other hand, according to the sex and class-level variables, there was a meaningful difference. These findings are in line with our study.

Tercanlı and Demir (2012) and in their study called "The evaluation of Beck Dissertation Scale some variables (Gümüşhane City Example)", the people living in Gümüşhane had some meaningful differences about their desperation levels in terms of the variables of education level, his or her husband or wife's education level and profession, income level, registered in the population hometown. On the other hand, there weren't meaningful differences according to the age, sex, marriage status, child number, if there were health insurance and the family model, there wasn't a meaningful difference. These findings are in line with our study.

According to Deveci, Ulutaşdemir and Açık (2011) and their study "The factors affecting the students' desertion levels of a vocational training center", they found out that the desperation levels of male participants, the participants who were working more than five days a week, the participants who changed their works, the participants who worked more than eight hours a day, the participants who didn't enjoy their works, the participants who had some chronic health problems, the participants who smoked a cigarette and had alcohol were higher than the other participants. These findings do not support our study.

Özçelik, Aktaş and Ocakçı (2014) explained in their study "The effect of career choice on the university first-class students' desperation levels" that the male participant students' desperation levels were higher than the female participant students. According to the income level variable, there wasn't a meaningful difference, but when it was looked at the mean scores according to lower-income positions, the desperation levels were higher. These findings do not support our study.

\section{Suggestion}

As a result of the data of this study, schools and all duty persons must lower the desperation levels of students because this feeling affects learning success and future expectations negatively.

\section{References}

Alexopoulos, G. S. (2019). Mechanisms and treatment of late-life depression. Translational Psychiatry, 9(1), 188. https://doi.org/10.1038/s41398-019-0514-6

Ayda, A. (2011). Defining the desperation levels of music department undergraduate students: Example of 
Hacettepe University Ankara State Conservatory. Gazi University, Education Faculty Journal, 31(2).

Belayihun, B., \& Mavhandu-mudzuis, A. H. (2018). Psychological distress in women with obstetric fistula in Ethiopia: A multi-center, facility based, cross-sectional study. Ethiopian Journal of Health Development, 32, 4.

Breslow, A. S., Tran, N. M., Lu, F. Q., Alpert, J. E., \& Cook, B. L. (2019). Depression Treatment Expenditures for Adults in the USA: A Systematic Review. Current Psychiatry Reports, 21(10), 105. https://doi.org/10.1007/s11920-019-1083-3

Cam, Ç. F., \& Erkorkmaz, U. (2008). Factors related to depressive symptoms and dissertation levels of university students. Archives of Neuropsychiatry, 45(4).

Ceyhan, A. A. (2004). Investigation of candidate teachers' desperation levels continuing master's program without thesis of secondary education branch/field teacher program. Anadolu University Journal of Social Sciences, 1, 91-101.

Cohen-Chen, S., Crisp, R. J., \& Halperin, E. (2017). Hope comes in many forms: Outgroup expressions of hope override low support and promote reconciliation in conflicts. Social Psychological and Personality Science, 8, 153-161. https://doi.org/10.1177/1948550616667612

Cohen-Chen, S., Halperin, E., Crisp, R. J., \& Gross, J. J. (2014). Hope in the Middle East: Malleability beliefs, hope, and the willingness to compromise for peace. Social Psychological and Personality Science, 5, 67-75. https://doi.org/10.1177/1948550613484499

Cohen - Chen, S., Lang, O., Ran, S., \& Halperin, E. (2020). The prevalence of despair in intractable conflicts: Direct messages of hope and despair affect leftists, but not rightists. Journal of Applied Social Psychology. https://doi.org/10.1111/jasp.12697

De Aguiar Neto, F. S., \& Rosa, J. (2019). Depression biomarkers using non-invasive EEG: A review. Neuroscience and Biobehavioral Reviews, 105, 83-93. https://doi.org/10.1016/j.neubiorev.2019.07.021

De Berardis, D., Fornaro, M., Orsolini, L., Valchera, A., Carano, A., Vellante, F. et al. (2017). Alexithymia and suicide risk in psychiatric disorders: A mini-review. Front Psychiatry, 8, 148. https://doi.org/10.3389/fpsyt.2017.00148

Deveci, S. E., Ulutaşdemir, N., \& Açık, Y. (2011). Desperation level and affecting factors of a Professional education center's students. Dicle Medicine https://doi.org/10.5798/diclemedj.0921.2011.03.0039

Doğan, P. (2012). Examining the art candidate teachers' dessertation levels. Marmara University Atatürk Education Faulty Journal of Educational Sciences, 36(36), 115-127.

Duko, B., Wolka, S., Seyoum, M., \& Tantu, T. (2020). Prevalence of depression among women with obstetric fistula in low-income African countries: A systematic review and meta-analysis. Archives of Women's Mental Health. https://doi.org/10.1007/s00737-020-01028-w

Górska, N., Słupski, J., Szałach, Ł. P., Włodarczyk, A., Szarmach, J., Jakuszkowiak-Wojten, K., ... Cubała, W. J. (2019). Magnesium and ketamine in the treatment of depression. Psychiatria Danubina, 31(Suppl 3), 549-553.

Grover, S., \& Avasthi, A. (2019). Clinical practice guidelines for the management of depression in children and $\begin{array}{lllll}\text { adolescents. Indian } \quad \text { Journal } & \text { 226-240. }\end{array}$ https://doi.org/10.4103/psychiatry.IndianJPsychiatry_563_18

Halperin, E., \& Gross, J. J. (2011). Emotion regulation in violent conflict: Reappraisal, hope, and support for humanitarian aid to the opponent in wartime. Cognition and Emotion, 25, 1228-1236. https://doi.org/10.1080/02699931.2010.536081

James, S. et al. (2018). Global, regional, and national incidence, prevalence, and years lived with disability for 354 diseases and injuries for 195 countries and territories, 1990-2017: A systematic analysis for the Global Burden of Disease Study 2017. Lancet, 393, 22-28. https://doi.org/10.1016/S0140-6736(18)32279-7

Jantaratnotai, N., Mosikanon, K., Lee, Y., \& McIntyre, R. S. (2017). The interface of depression and obesity. Obesity Research \& Clinical Practice, 11(1), 1-10. https://doi.org/10.1016/j.orcp.2016.07.003

Karasar, N. (2005). Scientific research methods. Ankara: Nobel Publishing.

Karayol, M., \& Dogar, Y. (2020). Examination of cognitive flexibility and social appearance anxiety levels of 
physical education and primary school teachers. Asian Journal of Education and Training, 6(2), 176-180. https://doi.org/10.20448/journal.522.2020.62.176.180

Kingston, J., Becker, L., Woeginger, J., \& Ellett, L. (2020). A randomised trial comparing a brief online delivery of mindfulness-plusvalues versus values only for symptoms of depression: Does baseline severity matter? Journal of Affective Disorders, 276, 936-944. https://doi.org/10.1016/j.jad.2020.07.087

Kula, K. Ş., \& Saraç, T. (2017). Analyzing the Hopelessness Level of the University Students: Example of Ahi Evran University. Journal of Social Sciences (Eskisehir Osmangazi University), 18(1), 1-16.

Lala, G., McGarty, C., Thomas, E. F., Ebert, A., Broderick, M., Mhando, M., \& Kamuronsi, Y. (2014). Messages of hope: Using positive stories of survival to assist recovery in Rwanda. Journal of Social and Political Psychology, 2(1), 451-468. https://doi.org/10.5964/jspp.v2i1.290

Moeschberger, S. L., Dixon, D. N., Niens, U., \& Cairns, E. (2005). Forgiveness in Northern Ireland: A model for peace in the midst of the "Troubles". Peace and Conflict: Journal of Peace Psychology, 11(2), 199-214. https://doi.org/10.1207/s15327949pac1102_5

Özçelik, Ç. Ç., Aktaş, E., \& Ocakçı, A. F. (2014). Effects of choicing profession on desperation levels of university 1st class students (college freshmen). Clinical and Experimental Health Sciences, 4(1), 10-16. https://doi.org/10.5455/musbed.20140207083728

Özmen, D., Dündar, P. E., Çetinkaya, A. Ç., Taşkın, O., \& Özmen, E. (2008). Factors affecting high school students' dessertation and dessertation levels. Anatolian Psychiatry Journal, 9(1), 8-15.

Rosler, N., Cohen-Chen, S., \& Halperin, E. (2017). The distinctive effects of empathy and hope in intractable conflicts. Journal of Conflict Resolution, 61, 114-139. https://doi.org/10.1177/0022002715569772

Şahin, C. (2009). The dessertation levels of students having education at faculty of education. Selçuk University Ahmet Keleşoğlu Education Faculty Journal, 27, 271-286.

Sallfors, C., Fasth, A., \& Hallberg, M. (2002). Oscillating between hope and despair: A qualitative study. Child Care, Health and Development, 28, 495-505. https://doi.org/10.1046/j.1365-2214.2002.00300.x

Sekhar, D. L., Ba, D. M., Liu, G., \& Kraschnewski, J. (2019). Major depressive disorder screening remains low even among privately insured adolescents. The Journal of Pediatrice, 204, 203-207. https://doi.org/10.1016/j.jpeds.2018.07.086

Stephens, T. N., Tran, M. M., Bunge, E. L., Liu, N. H., Barakat, S., Garza, M., \& Leykin, Y. (2020). Children and adolescents attempting to participate in a worldwide online depression screener. Psychiatry Research, 291, 113250. https://doi.org/10.1016/j.psychres.2020.113250

Tao, L., Jiang, R., Zhang, K., Qian, Z., Chen, P., Lv, Y., \& Yao, Y. (2020). Light therapy in non-seasonal depression: An update meta-analysis. Psychiatry Research, 291, 113247. https://doi.org/10.1016/j.psychres.2020.113247

Tercanl, N., \& Demir, V. (2012). Evaluation of Beck Dessertation Scale according to some variables (Gümüşhane city example). Gümüşhane University Health Sciences Journal.

Teshome, H. M., Derese, A., \& Abdeta, T. (2020). Depressive symptoms among Haramaya University students in Ethiopia: A cross-sectional study. Depression Research and Treatment, 2020. https://doi.org/10.1155/2020/5027918

Usher, W. (2020). Living in quiet desperation: The mental health epidemic in Australia's higher education. Health Education Journal, 79(2), 138-151. https://doi.org/10.1177/0017896919867438

Veness, B. (2016). The wicked problem of university student mental health. Report to the Winston Churchill Memorial Trust, Sydney, NSW, Australia, January. Retrieved from https://www.churchilltrust.com.au/media/fellows/Veness_B_2013_The_wicked_problem_of_university_stu dent_mental_health.pdf

\section{Copyrights}

Copyright for this article is retained by the author, with first publication rights granted to the journal.

This is an open-access article distributed under the terms and conditions of the Creative Commons Attribution license (http://creativecommons.org/licenses/by/4.0/). 